\title{
Effect of Kupffer cell phagocytosis blockade induced by gadolinium chloride and carrageenan on endotoxin sensitivity, tissue localization of endotoxin and TNF production
}

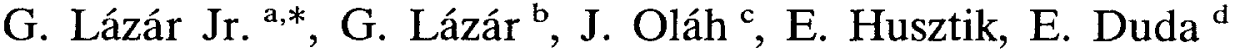 \\ ${ }^{\mathrm{a}}$ Department of Surgery, ${ }^{\mathrm{b}}$ Institute of Pathophysiology, ' Department of Dermatology, Albert Szent-Györgyi Medical University, and ${ }^{\mathrm{a}}$ Biological \\ Research Center of the Hungarian Academy of Sciences, Szeged, Hungary
}

\begin{abstract}
Several recent data suggest that in severe injuries, such as a shock state, the gradual activation of Kupffer cells and the excessive release of destructive and immunosuppressive products from macrophages may contribute to the development of "multiple organ failure". The effect of Kupffer cell phagocytosis blockade on the correlation between the tissue distribution of bacterial lipopolysaccharide (LPS), endotoxin sensitivity and LPS-induced tumor necrosis factor (TNF) production was investigated in in vivo experiments in mice. To depress the activity of the $\mathrm{Kupffer}$ cells, gadolinium chloride ( $\mathrm{GdCl}_{3}$ ) or carrageenan was used. The studies indicated the dissociation of the tissue localization of ${ }^{51} \mathrm{Cr}$-labeled endotoxin and endotoxin lethalithy. Both $\mathrm{GdCl}_{3}$ and carrageenan depressed the Kupffer cell activity, but the endotoxin sensitivity was enhanced only by carrageenan treatment. However, there was a close correlation between the sensitivity to LPS and LPS-induced TNF production as measured in the serum, since LPS-induced TNF production was enhanced only by carrageenan treatment.
\end{abstract}

Keywords: Kupffer cell; Phagocytosis blockade; Endotoxin; Tumor necrosis factor

\section{Introduction}

Kupffer cells normally serve as an effective filter, rapidly removing blood-borne particulate matter and gut-derived bacterial antigens from the portal circulation; they appear to be the major cell type responsible for the detoxification of bacterial LPS [1,2]. On the other hand, several recent literature data has prooven that in endotoxin/septic shock the hyperactivity of the macrophages and overproduction different mediators (TNF, IL1, IL6, IL8, PGE2 etc.) leads to the development of "multiple organ failure" [3].

Our earlier experiments demonstrated that rare earth metals salts, among them gadolinium chloride $\left(\mathrm{GdCl}_{3}\right)$, depress the reticuloendothelial (RES) activity [4] selectively depressing the phagocytic activity of Kupffer cells [5]. On this basis, we set out to study the effects of $\mathrm{GdCl}_{3}$ and another well-known RES depressant, carrageenan [6], on the correlation between the tissue distribution of LPS, endotoxin sensitivity and LPSinduced TNF production. Furthermore, we investigated

\footnotetext{
${ }^{*}$ Corresponding author.
}

the effects of these substances on TNF toxicity and production in vitro.

\section{Materials and methods}

CFLP male mice (Animal House, Gödöllô, Hungary) weighing $30-35 \mathrm{~g}$ were maintained on a standard laboratory diet and tap water ad libitum.

To depress the activity of Kupffer cells, $\mathrm{GdCl}_{3}$ or carrageenan was used. $\mathrm{GdCl}_{3}$ (K. and $\mathrm{K}$. Laboratories, Plainview, New York) was dissolved in $0.85 \%$ saline at a concentration of $2 \mathrm{mg} \mathrm{ml}^{-1}$ and was injected i.v. at a dose of $1 \mathrm{mg}(100 \mathrm{~g})^{-1}$ body weight $24 \mathrm{~h}$ before testing; kappa, lambda or iota carrageenan (Marine Colloid, Rochland) was dissolved in boiling $0.85 \%$ saline at a concentration of $10 \mathrm{mg} \mathrm{ml}^{-1}$, and was injected i.p. at a dose of $5 \mathrm{mg}(100 \mathrm{~g})^{-1}$ body weight $24 \mathrm{~h}$ before testing.

For the measurement of endotoxin sensitivity, mice were challenged i.p. with $250 \mu \mathrm{g}(10 \mathrm{~g})^{-1}$ body weight of endotoxin (E. coli 026:B6 lipopolysacharide B, Difco 
Lab., Detroit, lot 688839) and the number of survivors was recorded after $48 \mathrm{~h}$.

For organ uptake studies, ${ }^{51} \mathrm{Cr}$-labeled endotoxin was used by the method of Braude [7]. Animals were sacrificed $1 \mathrm{~h}$ following LPS injection.

TNF cytotoxicity was measured on mouse L929 tumor cells, in the presence of $1 \mu \mathrm{g} \mathrm{ml}^{-1}$ actinomycin-D, at exactly $37^{\circ} \mathrm{C}[8]$. Killing of cells was assessed by the reduction of MTT [9]. The amount of TNF required to mediate the half-maximal cytoxicity of $\mathrm{L} 929$ cells was assigned a value of $1 \mathrm{U}$.

\subsection{Data analysis}

The means after analysis of variance were compared by the method of Scheffe. Statistical significance was accepted at $p<0.05$. Survival data were analysed for statistical significance by the Fisher exact test.

\section{Results}

The data in Table 1 show that the animals were sensitized to LPS by carrageenan pretreatment as compared with controls treated only with LPS. All forms of carrageenan aggravated endotoxin lethalithy. Only $20 \%, 5 \%$ and $15 \%$ of the animals given kappa, lambda or iota carrageenan, respectively, survived the endotoxin challenge, as compared with $60 \%$ survival in the control group. The carrageenans also caused the retention of ${ }^{51} \mathrm{Cr}$-labeled LPS in the blood, and at the same time reduced the hepatic and increased the extrahepatic uptake of endotoxin (Fig. 1(a)).

In response to $\mathrm{GdCl}_{3}$ (Fig. 1(b)), the alterations in the RES function were very similar to those observed in mice pretreated with carrageenan, but in contrast with the effect of these substances, $\mathrm{GdCl}_{3}$ did not alter the endotoxin susceptibility of the mice (Table 1).

The effects of carrageenan and $\mathrm{GdCl}_{3}$ on the rate of LPS-induced TNF production in the serum, liver and spleen are shown in Fig. 2(a-c). Carrageenan significantly increased the TNF concentration in the serum and significantly decreased the TNF concentration in the liver as compared with the controls and the $\mathrm{GdCl}_{3}$-treated group. However, $\mathrm{GdCl}_{3}$ caused a

Table 1

Canageean pretreated animals versus controls

\begin{tabular}{llll}
\hline Treatment & $\begin{array}{l}\text { Living/total } \\
(48 \%)\end{array}$ & $\begin{array}{l}\text { Survival } \\
(\%)\end{array}$ & $\begin{array}{l}\text { Statistics } \\
\text { (vs 1) }\end{array}$ \\
\hline E (LPS) & $30 / 50$ & 60 & \\
Gd & $11 / 20$ & 55 & N.S. \\
Kappa C & $4 / 20$ & 20 & $p<0.01$ \\
Lambda C & $1 / 20$ & 5 & $p<0.001$ \\
Iota C & $3 / 20$ & 15 & $p<0.01$ \\
\hline
\end{tabular}

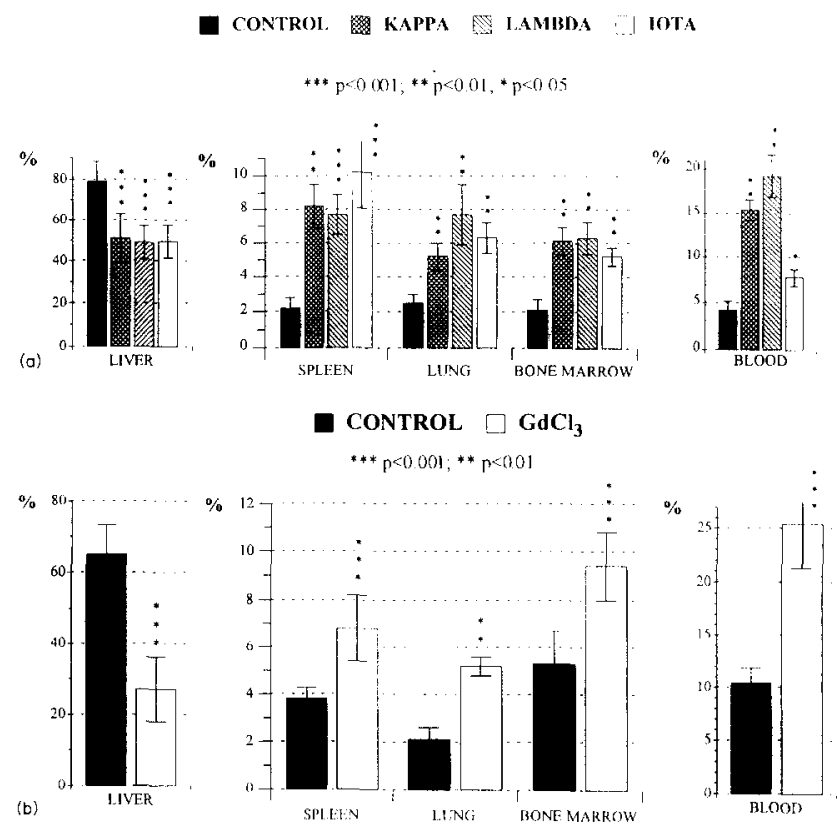

Fig. 1. (a) Effect of carrageenan and (b) $\mathrm{GdCl}_{3}$ (B) on distribution of LPS Carrageenan (i.p., $5 \mathrm{mg}(100 \mathrm{~g})^{-1}$ ) or $\mathrm{GdCl}_{3}$ (i.v., $1 \mathrm{mg}(100$ $\mathrm{g})^{-1}$ ) was injected $24 \mathrm{~h}$ before the i.v. injection of $250 \mu \mathrm{g}$ LPS labeled with ${ }^{51} \mathrm{Cr}$. The radiocontents of the organs and blood were determined $1 \mathrm{~h}$ later. All values are averages of 10 determinations, together with the standard error.

significant elevation of TNF in the spleen, in contrast with carrageenan, which did not alter the TNF production in this organ.

In vitro studies showed that carrageenan did not increase the LPS-induced TNF production in P388 cells or the constitutive synthesis of TNF in HeLa cells expressing human TNF under the control of a hybrid cellular/viral promoter, and did not affect the TNF sensitivity of L929 cells. Similarly, non-toxic concentrations of $\mathrm{GdCl}_{3}$ (up to $300 \mu \mathrm{g} \mathrm{ml}^{-1}$ ) did not have any influence on TNF production in the above cell cultures, but $100 \mu \mathrm{g} \mathrm{ml}^{-1} \mathrm{GdCl}_{3}$ protected mouse 3T3 cells against TNF cytotoxicity (data not shown).

\section{Discussion}

The relationship between the host RES/macrophage activity and endotoxin sensitivity is very complex. It is true that soon after the injection of endotoxin there is a deep depression in the RES activity and endotoxintolerant animals (induced by endotoxin pretreatment) have a hyperfunctional RES [10]. However, the classical macrophage stimulants such as BCG, zymosan, Corinebacterium parvum, and particulate glucan do not make experimental animals resistant to endotoxemia, but profoundly host susceptible to endotoxin [10].

Kupffer cells produce different mediators, including TNF, interleukin 1 and prostanglandin E2, which greatly influence the host immunoreactivity [11]. The importance of liver Kupffer cells as phagocytic cells is well 


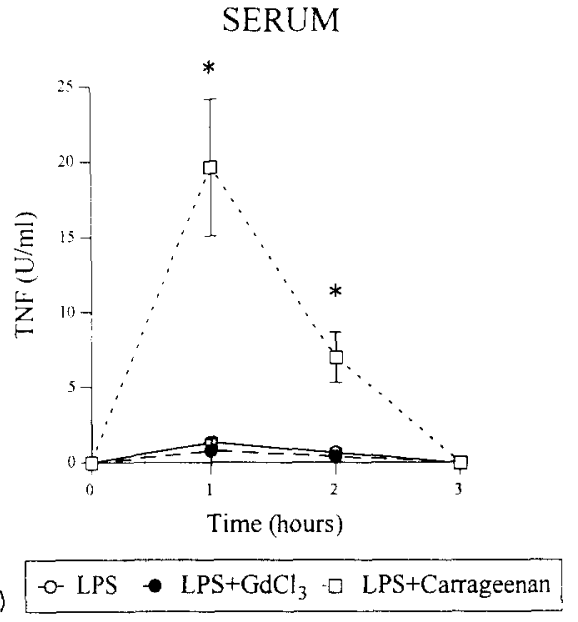

LIVER

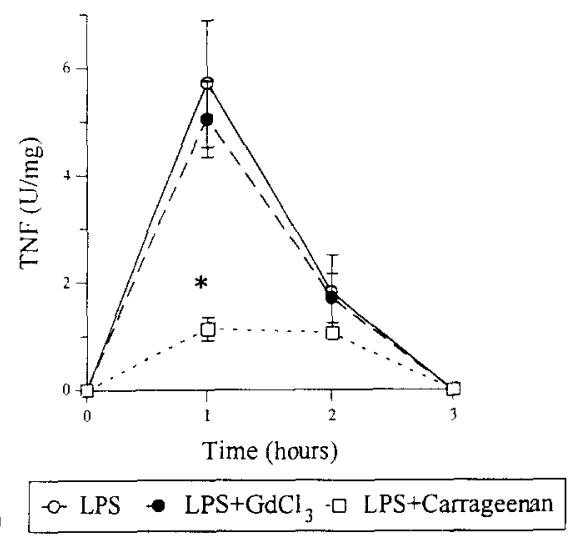

SPLEEN

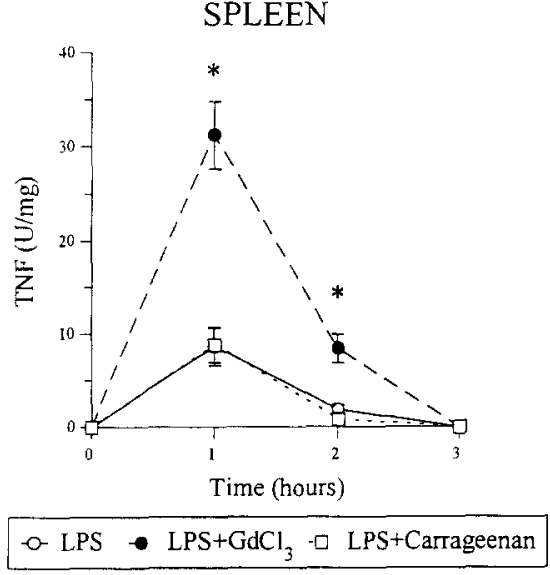

Fig. 2. Effects of $\mathrm{GdCl}_{3}$ and carrageenan on endotoxin-induced TNF production in: (a) blood; (b) liver; (c) spleen. Animals were given $\mathrm{GdCl}_{3}\left(1 \mathrm{mg}(100 \mathrm{~g})^{-1}\right)$, i.v. $)$ or carrageenan $\left(5 \mathrm{mg}(100 \mathrm{~g})^{-1}\right)$, i.p.) $24 \mathrm{~h}$ before the endotoxin challange $\left(1 \mu \mathrm{g} \mathrm{g}^{-1}\right.$, i.v.). TNF activity was measured 1, 2, 3 and $4 \mathrm{~h}$ after LPS treatment. Means of results on 10 mice per group.

recognized, and failure of this function has been implicated in the pathogenesis of multiple organ failure [12].
The present studies support earlier findings that the liver plays a major role in clearing endotoxins from the blood. However, the endotoxin-clearing capacity of the liver is not a crucial factor determining endotoxin sensivity. Our studies with carrageenan and $\mathrm{GdCl}_{3}$ indicate that these RES depressants delayed the vascular clearance of endotoxin and caused a great reduction in the hepatic localization of endotoxin, but only carrageenan enhanced the endotoxin sensitivity.

TNF is a lymphokine with powerful immunostimulating effects and causes severe systemic consequences at elevated levels [13]. Furthermore, TNF and other cytokines have been implicated in the pathogenesis of septic and endotoxin shock [14]. Our present studies revealed a close correlation with the sensitivity to LPSinduced TNF production as measured in the serum, for LPS-induced TNF production is enhanced only by carrageenan treatment. $\mathrm{GdCl}_{3}$ did not influence either the endotoxin toxicity or the circulating level of TNF. On the other hand, $\mathrm{GdCl}_{3}$ pretreatment significantly increased the LPS-induced TNF production of the spleen. These results support our earlier findings that the $\mathrm{GdCl}_{3}$ induced Kupffer cell phagocytosis blockade leads to the activation of spleen and, may explain some of the immunological effect of $\mathrm{GdCl}_{3}$.

\section{Acknowledgement}

This work was supported by the Hungarian National Science Foundation (OTKA, grant No.2684 and E 012054)

\section{References}

[1] R.W. Crofton, M.C. Martino, M.M.C. Diesselhof-den Dulk and R. van Furth, J. Exp. Med., 148 (1978) 1.

[2] J.C. Mathison and R. Ulevitch, J. Immunol., 123 (1979) 2133.

[3] J.R. Border, Arch. Surg., 123 (1988) 285.

[4] G. Lázár, J. Reticuloendothel. Soc., 13 (1973) 231.

[5] E. Husztik, G. Lázár and A. Párducz, Brit. J. Exp. Pathol., 61 (1980) 624.

[6] P.J. Catanzaro, H.J. Schwartz and R.C. Graham, Am. J. Pathol,, 64 (1971) 387.

[7] A.I. Braude, F.J. Carez, D. Sutherl and M. Yalesky, J. Clin. Invest., 34 (1955) 850.

[8] B.B. Aggarwal, W.J. Kohr and P.E. Hass, J. Biol. Chem., 260 (1985) 2345.

[9] T. Mosmann, J. Immunol. Methods, 65 (1983) 55.

[10] G. Lázár, E. Husztik, S. Ribárszki and S. Pintér, in M.K. Agarwal and M. Yoshida (eds.,) Immunpharmacology of Endotoxicosis, Walter de Gruyter, Berlin, New York, 1984, p. 1.

[11] T. Decker, M. L. Lohmann-Matthes, U. Karck, T. Peters and K. Decker, J. Leukocyte. Biol., 54 (1989) 139.

[12] U. Schoeffel, M. Widfuhr, N. Freudenburg, K.H. Treutner, E. Jacobs and C.H. Galanos, Circ. Shock, 27 (1989) 83.

[13] C.S. Rock and S.F.L. Lowry, J. Surg. Res., 51 (1991) 434.

[14] K.J. Tracey, Circ. Shock, 35 (1991) 123. 